\title{
Loss and Efficiency Analysis of BLDC Motor and Universal Motor by Mathematical Modelling in the Mixer Grinder
}

\author{
Deekshitha S Nayak ${ }^{1} \cdot$ R. Shivarudraswamy ${ }^{1}$ (B)
}

Received: 24 June 2019/Accepted: 12 July 2021 / Published online: 14 September 2021

(C) The Author(s) 2021

\begin{abstract}
The typical mixer grinders are universal motor, which operates on alternating current supply because of the higher starting torque characteristics and easy speed control. The absence of brushes in the Brushless DC (BLDC) motor and noise reduction improves its life and makes it perfectly suited for mixer grinder. The mathematical modelling and experimental demonstration of a conventional universal motor and proposed simulated model of BLDC motor was analysed using the MATLAB/Simulink. The loss and efficiency analysis of the permanent magnet BLDC and universal motor in the application of a mixer grinder are presented in this paper.
\end{abstract}

Keywords BLDC motor - Universal motor - Efficiency · Mixer grinder $\cdot$ MATLAB

\section{Introduction}

In a present scenario, the demand for scarce energy resources had necessitated energy-efficient appliances [1]. In all domestic appliances, either universal motor, DC motor, permanent magnet synchronous motor or induction motor is used [2]. In a mixer grinder appliance, a universal motor is used due to its higher starting torque and operating speed than the induction motor [3]. The universal motor operates same as DC series motor. The rotor and stator windings are in series, and the commutator and brush arrangements supply power to the rotor [4]. The design of

R. Shivarudraswamy

shivarudraswamy.r@manipal.edu

1 Department of Electrical and Electronics Engineering, Manipal Institute of Technology, MAHE, Manipal, India the universal motor is cheaper to achieve greater speed for smaller devices [5]. However, the wear-out of the commutator and brush in the universal motor can cause sparking and electromagnetic interference [6]. So, the BLDC motor is suitable for the mixer grinder because of its easy speed torque control and compact size [7]. In a few cases, the quality of the mixing material will affect when the mixer grinder is operated at low speed (3000 rpm), which is possible in the BLDC motor [8]. As the torque vs. efficiency characteristics of the BLDC motor is almost flat, the mixer operating at low speed and part load also save energy [9]. In rural India, the availability of power is poor and the load connected is around $300 \mathrm{~W}$. So the proposed BLDC motor power output was fixed at $200 \mathrm{~W}$ and the power input was limited to $250 \mathrm{~W}$. The $200 \mathrm{~W}$ output power of a BLDC motor is equivalent to existing $500 \mathrm{~W}$ universal motor of the mixer grinder.

This paper contributes in an application of a mixer grinder to the performance and losses analysis of a conventional universal motor and proposed BLDC motor. The proposed BLDC motor has lower power consumption compared to the existing universal motor available in a market.

\section{Mathematical Modelling of a Universal Motor}

In a universal motor's mathematical modelling, with the following assumptions voltage equations are given as:

a) Magnetic field shows harmonic layout in an air gap;

b) Perfect commutating armature; and

c) The effect of commutation is ignored [10].

Figure 1 describes the two pole circuit equivalent of a AC universal motor. $R_{1}$ is resistance of stator, $R_{2}$ is resistance of rotor machine, $L_{1}$ is stator inductance, $L_{2}$ is 


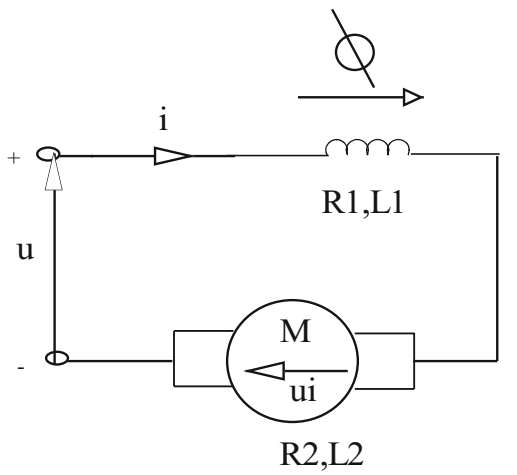

Fig. 1 AC operating universal motor equivalent circuit

machine rotor inductance, $\Phi$ is the magnetic flux in the stator, and $u_{\mathrm{i}}$ is an induced internal armature voltage [11].

Figure 2 represents a DC equivalent circuit of an universal motor. $V_{\mathrm{t}}$ is a supply voltage, $E$ is a back emf, ra is a resistance of the stator, $\mathrm{rf}$ is the resistance of the rotor, $I_{\mathrm{a}}$ is the current in the armature, $I_{\mathrm{f}}$ is an excitation current, $V_{\mathrm{f}}$ is the excitation voltage, $L_{\mathrm{ff}}$ is self-inductance of the rotor, and $L_{\mathrm{aa}}$ is self-inductance of the stator. The mathematical modelling equations are given as [12]:

$I_{\mathrm{f}}=I_{\mathrm{a}}$

$V_{\mathrm{f}}=r_{\mathrm{f}} I_{\mathrm{a}}+L_{\mathrm{ff}}\left(\frac{\mathrm{d} I_{\mathrm{a}}}{\mathrm{d} t}\right)$

$E=L_{\mathrm{af}} \omega I_{\mathrm{a}}$

$V_{\mathrm{a}}=r_{\mathrm{a}} I_{\mathrm{a}}+L_{\mathrm{aa}}\left(\frac{\mathrm{d} I_{\mathrm{a}}}{\mathrm{d} t}\right)+E$

$V_{\mathrm{a}}=r_{\mathrm{a}} I_{\mathrm{a}}+L_{\mathrm{aa}}\left(\frac{d I_{a}}{d t}\right)+\left(L_{\mathrm{af}} \omega I_{\mathrm{a}}\right)$

$V_{\mathrm{t}}=V_{\mathrm{a}}+V_{\mathrm{f}}$

$V_{\mathrm{t}}=I_{\mathrm{a}}\left(r_{\mathrm{f}}+r_{\mathrm{a}}+L_{\mathrm{af}} \omega\right)+\left(\frac{\mathrm{d} I_{\mathrm{a}}}{\mathrm{d} t}\right)\left(L_{\mathrm{ff}}+L_{\mathrm{aa}}\right)$

The mechanical equations of the motor are:

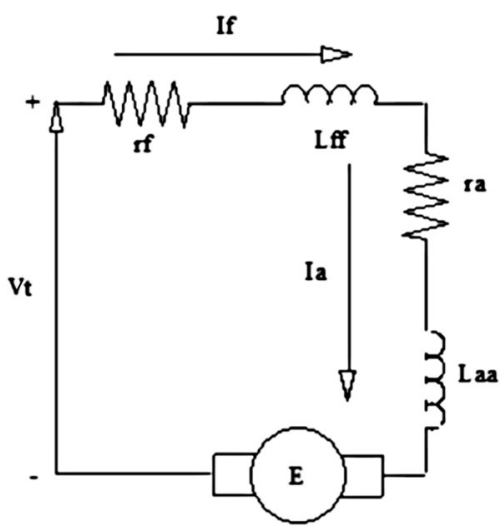

Fig. 2 Equivalent DC circuit in universal motor operation [5]
$T_{\mathrm{e}}=L_{\mathrm{af}} I_{\mathrm{a}} I_{\mathrm{f}}$

$T_{\mathrm{e}}=J \frac{\mathrm{d} \omega}{\mathrm{d} t}+B \omega+T_{1}$

$\frac{\mathrm{d} \omega}{\mathrm{d} t}=\left(-\frac{B}{J}\right) \omega+\frac{\left(T_{\mathrm{e}}-T_{\mathrm{L}}\right)}{J}$

$\omega=\int\left(\left(\frac{-B}{J}\right) \omega+\frac{\left(T_{e}-T_{L}\right)}{J}\right) \mathrm{d} t$

where $J$ is the coefficient of inertia, $T_{\mathrm{L}}$ is a load torque, $T_{\mathrm{e}}$ is an electromagnetic torque, $\omega$ is a rotor mechanical speed, $B$ is the coefficient of friction and $\Omega$ is angular velocity [13].

\section{Losses of Universal Motor Equations}

Per slot copper loss:

$J=\frac{I N}{A}$

$P_{\text {Cu..slot }}=I^{2} R=J^{2} A \rho l_{\text {turn }}$

where $J$ is a current density, $I$ is current, $A$ is a slot, $L_{\text {turn }}$ is a winding turn length, $\rho$ is the copper specific resistance and $N$ is a number of turns [14].

Hysteresis loss:

$P_{\mathrm{h}}=k_{\mathrm{h}} B_{\text {max }}^{n} f$

where $k_{\mathrm{h}}$ is the constant of hysteresis (ranges from 0.1 to $0.6), \mathrm{f}$ is the frequency of flux reversal in the rotor $(50 \mathrm{~Hz})$, $B$ is a maximum flux density (2-4 Tesla) and $n$ is a material-dependent exponents ranges from 1.5 to 2.5 .

Eddy current losses:

$P_{\mathrm{e}}=k_{\mathrm{e}} B^{2} f^{2} m$

where $k_{\mathrm{e}}$ is the Eddy current constant (almost equal to 1, i.e. 0.8$)$, $\mathrm{f}$ is the frequency of flux reversal in a rotor $(50 \mathrm{~Hz})$ and $B$ is a maximum flux density (2-4 Tesla).

The square of frequency influences the eddy current losses, and hysteresis losses rise linearly with the frequency.

Field copper loss:

$P_{\text {fieldcu }}=I_{\mathrm{se}}^{2} R_{\mathrm{se}}$

where $I_{\text {se }}$ is the field winding current in series and $R_{\text {se }}$ is the field winding resistance in series [15].

\section{Mathematical Modelling of a BLDC Motor}

Considering a cylindrical stator and rotor in three phases, with windings $a, b$ and $c$. The rotor consists of a permanent magnet with air gap uniform as stator consists of three phase bounded by star connected [16]. For phase $a$, phase $b$ and phase $c$, the dynamic equations are: 
$V_{\mathrm{an}}=R_{\mathrm{S}} i_{\mathrm{a}}+L \frac{\mathrm{d} i_{\mathrm{a}}}{\mathrm{d} t}+M \frac{\mathrm{d} i_{\mathrm{b}}}{\mathrm{d} t}+M \frac{\mathrm{d} i_{\mathrm{c}}}{\mathrm{d} t}+e_{\mathrm{a}}$

$V_{\mathrm{bn}}=R_{\mathrm{S}} i_{\mathrm{b}}+L \frac{\mathrm{d} i_{\mathrm{b}}}{\mathrm{d} t}+M \frac{\mathrm{d} i_{\mathrm{c}}}{\mathrm{d} t}+M \frac{\mathrm{d} i_{\mathrm{a}}}{\mathrm{d} t}+e_{\mathrm{b}}$

$V_{\mathrm{cn}}=R_{\mathrm{S}} i_{\mathrm{c}}+L \frac{\mathrm{d} i_{\mathrm{c}}}{\mathrm{d} t}+M \frac{\mathrm{d} i_{\mathrm{a}}}{\mathrm{d} t}+M \frac{\mathrm{d} i_{\mathrm{b}}}{\mathrm{d} t}+e_{\mathrm{c}}$

where $M$ is armature mutual inductance, $R$ is armature resistance, $V_{\mathrm{an}}, V_{\mathrm{bn}}$ and $V_{\mathrm{cn}}$ are the voltage of the terminals, $L$ is armature self-inductance, and $i_{\mathrm{a}}, i_{\mathrm{b}}$ and $i_{\mathrm{c}}$ are input currents of the motor [17].

$$
\begin{aligned}
{\left[\begin{array}{l}
V_{\mathrm{an}} \\
V_{\mathrm{bn}} \\
V_{\mathrm{cn}}
\end{array}\right]=} & {\left[\begin{array}{ccc}
R_{\mathrm{S}} & 0 & 0 \\
0 & R_{\mathrm{S}} & 0 \\
0 & 0 & R_{\mathrm{S}}
\end{array}\right]\left[\begin{array}{c}
i_{\mathrm{a}} \\
i_{\mathrm{b}} \\
i_{\mathrm{c}}
\end{array}\right]+\left[\begin{array}{ccc}
L & M & M \\
M & L & M \\
M & M & L
\end{array}\right]\left[\begin{array}{c}
\mathrm{d} i_{\mathrm{a}} \\
\mathrm{d} t \\
\frac{\mathrm{d} i_{\mathrm{b}}}{\mathrm{d} t} \\
\frac{\mathrm{d} i_{\mathrm{c}}}{\mathrm{d} t}
\end{array}\right] } \\
& +\left[\begin{array}{c}
e_{\mathrm{a}} \\
e_{\mathrm{b}} \\
e_{\mathrm{c}}
\end{array}\right]
\end{aligned}
$$

The rotor position function in a BLDC motor is related to the back emf. Each back emf phases has a difference of $120^{\circ}$ angle of phase [18]. Hence, the equations for each phase are:

$e_{\mathrm{a}}=K_{\mathrm{a}} f_{\mathrm{a}}(\theta) \omega_{\mathrm{r}}$

$e_{\mathrm{b}}=K_{\mathrm{b}} f_{\mathrm{b}}\left(\theta+\frac{2 \pi}{3}\right) \omega_{\mathrm{r}}$

$e_{\mathrm{c}}=K_{\mathrm{c}} f_{\mathrm{c}}\left(\theta-\frac{2 \pi}{3}\right) \omega_{\mathrm{r}}$

$\left[\begin{array}{c}V_{\mathrm{an}} \\ V_{\mathrm{bn}} \\ V_{\mathrm{cn}}\end{array}\right]=\left[\begin{array}{ccc}R_{\mathrm{s}} & 0 & 0 \\ 0 & R_{\mathrm{s}} & 0 \\ 0 & 0 & R_{\mathrm{s}}\end{array}\right]\left[\begin{array}{c}i_{\mathrm{a}} \\ i_{\mathrm{b}} \\ i_{\mathrm{c}}\end{array}\right]+L_{s}\left[\begin{array}{c}\frac{\mathrm{d} i_{\mathrm{a}}}{\mathrm{d} t} \\ \frac{\mathrm{d} i_{\mathrm{b}}}{\mathrm{d} t} \\ \frac{\mathrm{d} i_{\mathrm{c}}}{\mathrm{d} t}\end{array}\right]+\left[\begin{array}{c}e_{\mathrm{a}} \\ e_{\mathrm{b}} \\ e_{\mathrm{c}}\end{array}\right]$

The total torque is given as:

$e_{\mathrm{a}}=K_{\mathrm{a}} \omega_{\mathrm{r}}$

$P_{\mathrm{m}}=e_{\mathrm{a}} i_{\mathrm{a}}+e_{\mathrm{b}} i_{\mathrm{b}}+e_{\mathrm{c}} i_{\mathrm{c}}$

$T_{\mathrm{e}}=\frac{P_{\mathrm{m}}}{\omega_{\mathrm{rm}}}=\frac{\left(e_{\mathrm{a}} i_{\mathrm{a}}+e_{\mathrm{b}} i_{\mathrm{b}}+e_{\mathrm{c}} i_{\mathrm{c}}\right)}{\omega_{\mathrm{r}}} \frac{P}{2}$

$T_{\mathrm{e}}=\frac{P\left(K_{\mathrm{a}} i_{\mathrm{a}}+K_{\mathrm{b}} i_{\mathrm{b}}+K_{\mathrm{c}} i_{\mathrm{c}}\right)}{2}$

Mechanical part:

$$
\begin{aligned}
& T_{\mathrm{e}}-T_{\mathrm{L}}=J \frac{\mathrm{d} \omega_{\mathrm{rm}}}{\mathrm{d} t}+B \omega_{\mathrm{rm}} \\
& \frac{\mathrm{d} \omega_{\mathrm{rm}}}{\mathrm{d} t}=\frac{P}{2 J}\left(T_{\mathrm{e}}-T_{\mathrm{L}}-\frac{2 B}{P} \omega_{\mathrm{r}}\right)
\end{aligned}
$$

where $T_{\mathrm{L}}$ is a load torque, $J$ is a current density, $T_{\mathrm{e}}$ is an electromagnetic torque and $B$ is a flux density [7].

\section{Losses Equations of the BLDC Motor}

Hysteresis loss:

$W_{\mathrm{h}}=k_{\mathrm{h}} B_{\max }^{\alpha} f$

where $f$ is the frequency of flux reversal in the rotor $(50 \mathrm{~Hz}), B_{\max }$ is the maximum flux density (0.638 Tesla), $k_{\mathrm{h}}$ is the hysteresis constant (ranges from 0.1 to 0.6 ) and $\propto$ is the constant (1.5-2.5).

Copper loss:

$W_{\mathrm{cu}}=I_{\mathrm{rms}}^{2} R_{\mathrm{a}}$

where $I_{\mathrm{rms}}$ is the current RMS value and $R_{\mathrm{a}}$ is the armature resistance.

Eddy current loss:

$W_{\mathrm{e}}=k_{\mathrm{e}} B_{\max }^{2} f^{2}$

where $k_{\mathrm{e}}$ is the eddy current constant (almost equal to 1, i.e. $0.8), \mathrm{f}$ is the frequency of flux reversal in a rotor $(50 \mathrm{~Hz})$ and $B$ is the maximum flux density $(0.638$ Tesla) $[20,21]$.

\section{Simulink Model of an Universal Motor}

Table 1 presents Simulink model specification of an AC operating universal motor. The conventional mixer grinder of $600 \mathrm{~W}$ power rated with voltage of $230 \mathrm{~V} \mathrm{AC}$ and rated speed of 20,000 rpm was considered. The operating torque is based on the size of a jar (0.4 Litre, 1.3 Litres and 1.8 Litres) and the materials used. As per the market available mixer grinders, the required torque is in the range of $0.2-0.4 \mathrm{Nm}$. Figure 3 demonstrates Simulink model of an universal motor in state of AC operation.

Table 2 depicts parameters of Simulink model of a DC operating universal motor. A mixer grinder speed of $20,000 \mathrm{rpm}, 600 \mathrm{~W}$ rated power, current of $2.73 \mathrm{~A}$ and voltage of $220 \mathrm{~V}$ DC was considered. Figure 4 depicts the Simulink model of a DC operating universal motor. Due to the presence of resistance, the current gets restricted, and there is no effect of saturation.

Figure 5 shows the load torque vs. speed characteristics of AC and DC operating the universal motor. For different speeds, the load torque at DC operating condition was more than the AC operating condition. Due to the presence of reactance in the $\mathrm{AC}$ operating condition of the universal motor, there was a drop in the speed curve.

Table 3 presents a Simulink model parameters of BLDC motor. A mixer grinder with a speed of $10,000 \mathrm{rpm}, 200 \mathrm{~W}$ rated power and voltage of $48 \mathrm{~V}$ was considered. Figure 6 shows the Simulink model of a BLDC motor. 
Table 1 Specifications of the AC universal motor Simulink model [5]

\begin{tabular}{ll}
\hline Rated power & $600 \mathrm{~W}$ \\
Voltage input & $230 \mathrm{~V} \mathrm{AC}$ \\
Current & $2.61 \mathrm{~A}$ \\
Speed & $20,000 \mathrm{rpm}$ \\
Stator resistance & $2.04 \Omega$ \\
Rotor resistance & $1.6 \Omega$ \\
Self-inductance of rotor & $87 \mathrm{mH}$ \\
Self-inductance of Stator & $73 \mathrm{mH}$ \\
Mutual inductance & $2.86 \mathrm{mH}$ \\
Friction coefficient $(B)$ & $1.687 \mathrm{e}-5 \mathrm{Nms}^{2}$ \\
Inertial coefficient $(\mathrm{J})$ & $3.23 \mathrm{e}-4 \mathrm{~kg} \mathrm{~m}^{2}$ \\
\hline
\end{tabular}

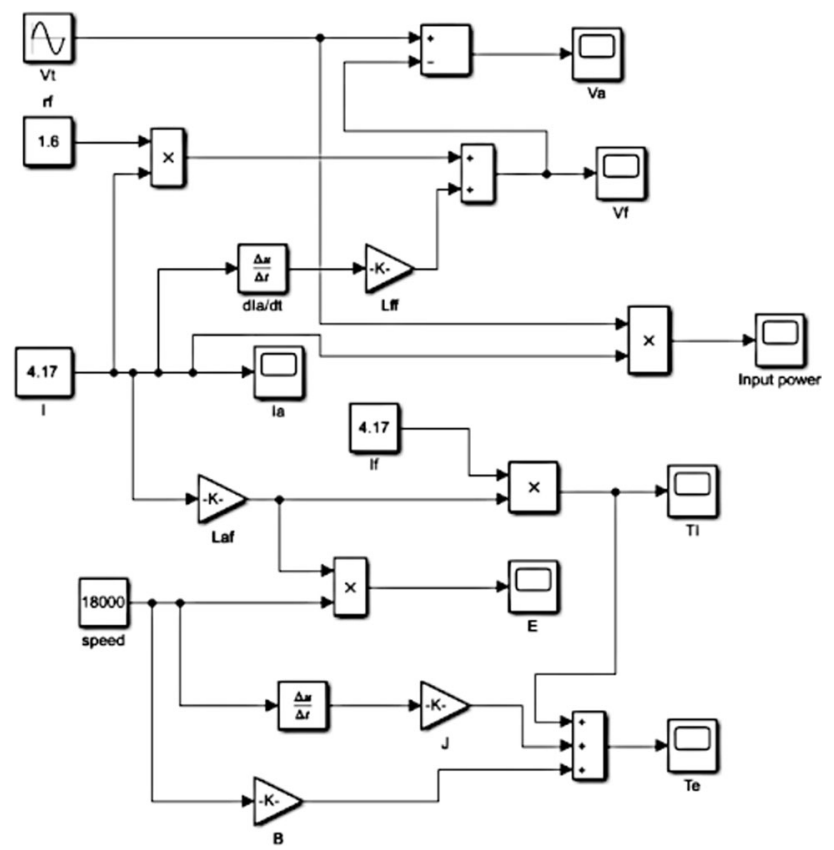

Fig. 3 Simulink model of an AC operating universal motor

Table 2 Specifications of the DC universal motor Simulink model [5]

\begin{tabular}{ll}
\hline Rated power & $600 \mathrm{~W}$ \\
Input voltage & $220 \mathrm{~V} \mathrm{DC}$ \\
Current & $2.73 \mathrm{~A}$ \\
Speed & $20,000 \mathrm{rpm}$ \\
Stator resistance & $2.04 \Omega$ \\
Rotor resistance & $1.6 \Omega$ \\
Self-inductance of rotor & $87 \mathrm{mH}$ \\
Self-inductance of stator & $73 \mathrm{mH}$ \\
Mutual inductance & $2.86 \mathrm{mH}$ \\
Friction coefficient $(B)$ & $1.687 \mathrm{e}-5 \mathrm{Nms}^{2}$ \\
Inertial coefficient $(\mathrm{J})$ & $3.23 \mathrm{e}-4 \mathrm{~kg} \mathrm{~m}^{2}$ \\
\hline
\end{tabular}

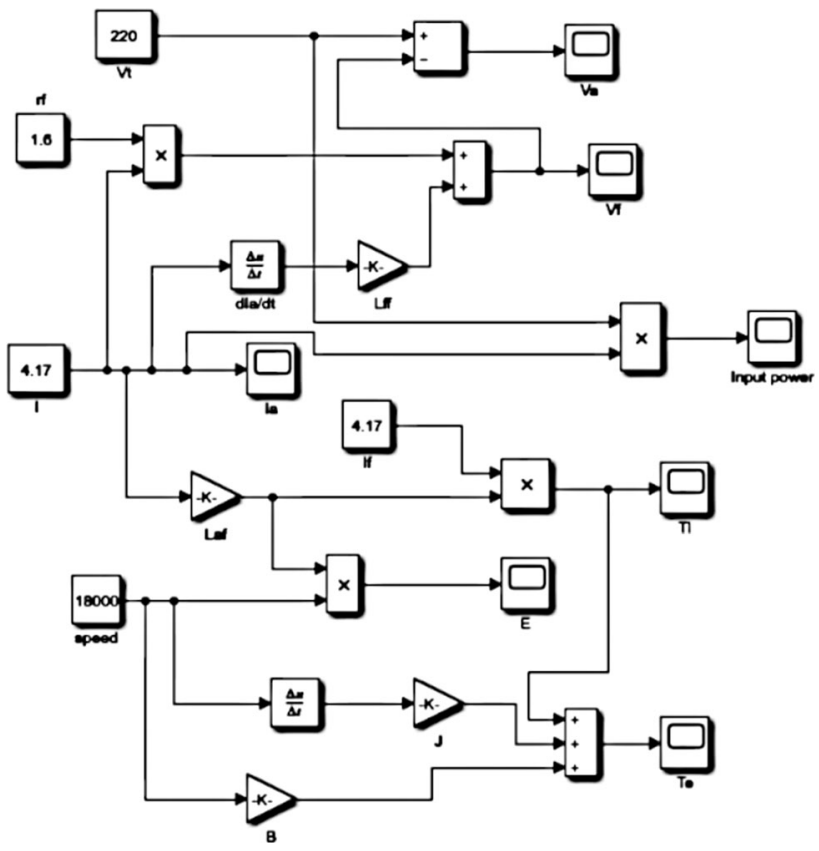

Fig. 4 Simulink model of the DC operating universal motor

Figure 7 represents the load torque vs. speed characteristics of a $48 \mathrm{~V}$ BLDC motor. The torque decreases with an increase in speed. It can be observed that the starting torque was higher in the BLDC motor than in the universal motor.

Figure 8 shows the efficiency vs. speed characteristics of AC and DC operating the universal motor and BLDC motor for different speeds. It can be seen that the efficiency of an AC operating universal motor is $52.16 \%$, and the DC operating universal motor efficiency is $54.5 \%$, while that of the $48 \mathrm{~V}$ BLDC motor is $81.15 \%$. The efficiency of $48 \mathrm{~V}$ BLDC motor is higher than $230 \mathrm{~V}$ AC and $220 \mathrm{~V} \mathrm{DC}$ operating universal motor.

\section{Losses Analysis of the Universal Motor and BLDC Motor}

Efficiency is the ratio of power output to power input, depending on the different power losses, i.e. iron loss, ventilation loss, copper loss, friction loss, mechanical loss and so on. The losses in the $230 \mathrm{~V}$ and $220 \mathrm{~V}$ universal motor and $48 \mathrm{~V}$ BLDC motor are depicted in Tables 4, 5 and 6.

Tables 4, 5 and 6 show that the losses in the $48 \mathrm{~V}$ BLDC motor are lesser than those in the $230 \mathrm{~V} \mathrm{AC}$ and $220 \mathrm{~V} \mathrm{DC}$ universal motor. The loss in the $220 \mathrm{~V}$ DC universal motor is lesser than in the $230 \mathrm{~V}$ AC universal motor.

Philips HL 1643/04 model is configured to prove experimental. The model specifications are $600 \mathrm{~W}, 230 \mathrm{~V}$ and speed of 20,000 rpm. The energy and power quality 


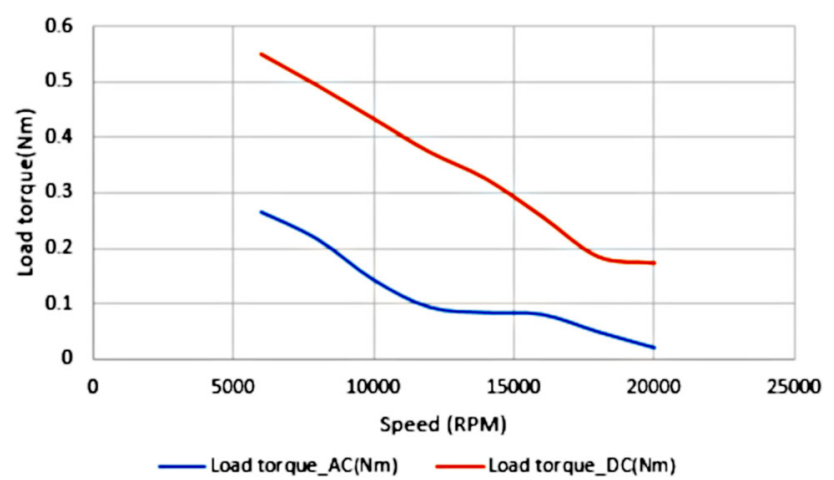

Fig. 5 Load torque versus speed characteristics of AC and DC operating a universal motor

Table 3 Parameters of BLDC motor's Simulink model

\begin{tabular}{ll}
\hline Power & $200 \mathrm{~W}$ \\
Voltage input & $48 \mathrm{~V}$ \\
Rated speed & $10,000 \mathrm{RPM}$ \\
Resistance of stator $\left(\mathrm{R}_{\mathrm{s}}\right)$ & $0.06 \mathrm{ohms}$ \\
Inductance of stator $\left(\mathrm{L}_{\mathrm{s}}\right)$ & $0.006 \mathrm{mH}$ \\
Coefficient of friction $(B)$ & $0.0682 \mathrm{e}-3$ \\
Number of poles $(\mathrm{P})$ & 4 \\
Inertial coefficient $(\mathrm{J})$ & $21.5 \mathrm{e}-3 \mathrm{~J} / \mathrm{kgm}^{2}$ \\
\hline
\end{tabular}

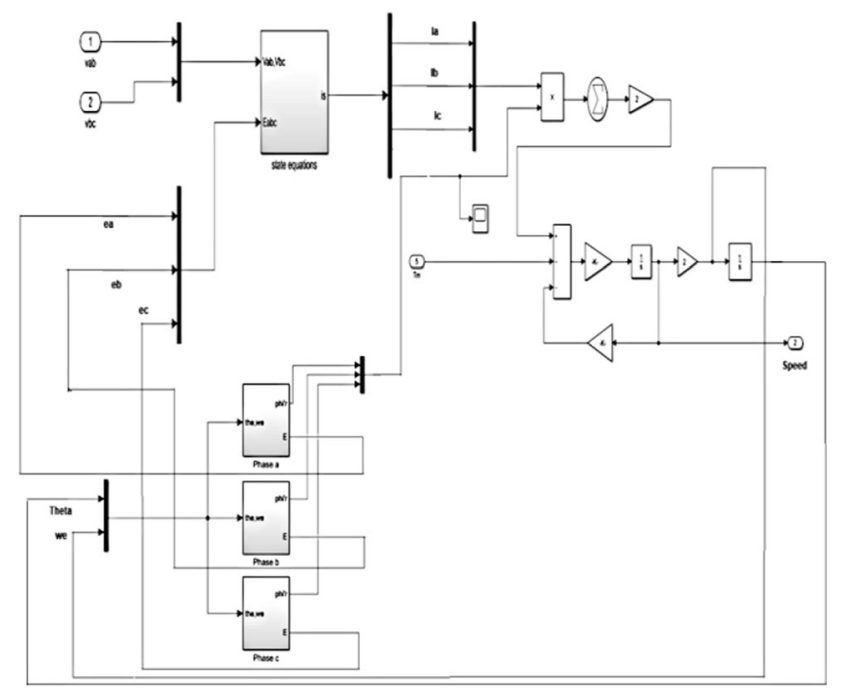

Fig. 6 Simulink model of $48 \mathrm{~V}$ BLDC motor

analyser of the Flux 435 series II is used to take the readings as depicted in Fig. 9.

Comparison of proposed simulated $48 \mathrm{~V}$ BLDC motor and experimental conventional mixer grinder is presented in Tables 7 and 8. Compared to the proposed system, the amount of distortion is high in the existing one. When the

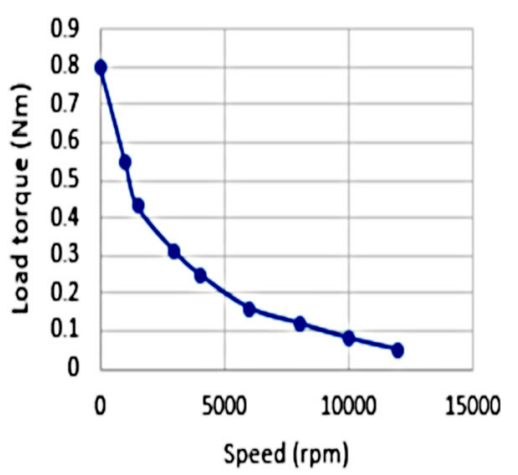

Fig. 7 Load torque versus speed characteristics of 48 V BLDC motor
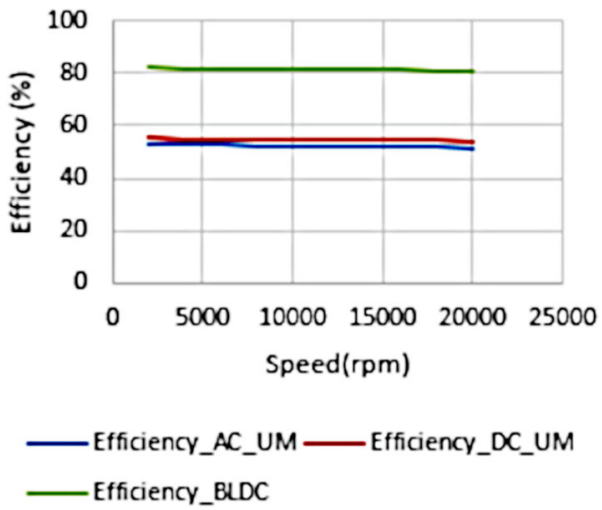

Fig. 8 Efficiency versus speed characteristics of a universal motor and BLDC motor

Table 4 Universal motor of $230 \mathrm{~V}$ AC operating losses

\begin{tabular}{ll}
\hline $\begin{array}{l}\text { Percentage of losses in universal } \\
\text { motor 230 V AC }\end{array}$ & $\begin{array}{l}\text { Loss wattage in 230 V AC } \\
\text { universal motor }\end{array}$ \\
\hline Efficiency $=52.16 \%$ & Rated power $=500 \mathrm{~W}$ \\
Field winding $=8.4 \%$ & Field winding $=42 \mathrm{~W}$ \\
Armature copper $=14.4 \%$ & Armature copper $=72 \mathrm{~W}$ \\
Stray load $=2.14 \%$ & Stray load $=10.7 \mathrm{~W}$ \\
Mechanical $=3.62 \%$ & Mechanical loss $=18.1 \mathrm{~W}$ \\
Hysteresis $=9.3 \%$ & Hysteresis $=46.5 \mathrm{~W}$ \\
$\begin{array}{l}\text { Eddy current }=8.07 \% \\
\text { Brush }+ \text { friction }+ \text { ventilation } \\
\text { loss }=1.91 \%\end{array}$ & $\begin{array}{c}\text { Eddy current }=40.35 \mathrm{~W} \\
\text { Brush }+ \text { friction }+ \text { ventilation } \\
\text { loss }=9.55 \mathrm{~W}\end{array}$ \\
\hline
\end{tabular}

crest factor is 1.42 , no distortion exists, and if the crest factor is greater than 1.8 , then high distortion occurs. The total harmonic distortion of a voltage and current is high in the conventional compared to the proposed system. So, it can be concluded that the proposed 48V BLDC motor has a 
Table 5 Losses of $220 \mathrm{~V}$ DC universal motor

\begin{tabular}{ll}
$\begin{array}{l}\text { Percentage of losses in 220 V DC } \\
\text { universal motor }\end{array}$ & $\begin{array}{l}\text { Wattage of losses in 220 V DC } \\
\text { universal motor }\end{array}$ \\
\hline Efficiency $=54.5 \%$ & Rated power $=500 \mathrm{~W}$ \\
Armature copper $=14.3 \%$ & Armature copper $=71.5 \mathrm{~W}$ \\
Field winding $=8.2 \%$ & Field winding $=41 \mathrm{~W}$ \\
Stray load $=2.09 \%$ & Stray load $=10.45 \mathrm{~W}$ \\
Mechanical $=3.21 \%$ & Mechanical $=16.05 \mathrm{~W}$ \\
Hysteresis $=9.21 \%$ & Hysteresis $=46.05 \mathrm{~W}$ \\
Eddy current $=7.17 \%$ & Eddy current $=35.85 \mathrm{~W}$ \\
Friction + brush + ventilation & Friction + brush + ventilation \\
loss $=1.32 \%$ & loss $=6.6 \mathrm{~W}$ \\
\hline
\end{tabular}

Table 6 Losses of 48 V BLDC motor

\begin{tabular}{ll}
\hline $\begin{array}{l}\text { Percentage of losses in } 48 \mathrm{~V} \\
\text { BLDC motor }\end{array}$ & $\begin{array}{l}\text { Wattage of losses in 48 V BLDC } \\
\text { motor }\end{array}$ \\
\hline Efficiency $=81.15 \%$ & Rated power $=200 \mathrm{~W}$ \\
Resistive loss $=0.5 \%$ & Resistive loss $=1 \mathrm{~W}$ \\
Winding loss $=3.76 \%$ & Winding loss $=7.52 \mathrm{~W}$ \\
Mechanical loss $=2.02 \%$ & Mechanical loss $=4.04 \mathrm{~W}$ \\
Stray load loss $=1.57 \%$ & Stray load loss $=3.14 \mathrm{~W}$ \\
Eddy current loss $=4.35 \%$ & Eddy current loss $=8.7 \mathrm{~W}$ \\
Hysteresis loss $=6.15 \%$ & Hysteresis loss $=12.3 \mathrm{~W}$ \\
Friction loss $=0.5 \%$ & Friction loss $=1 \mathrm{~W}$ \\
\hline
\end{tabular}

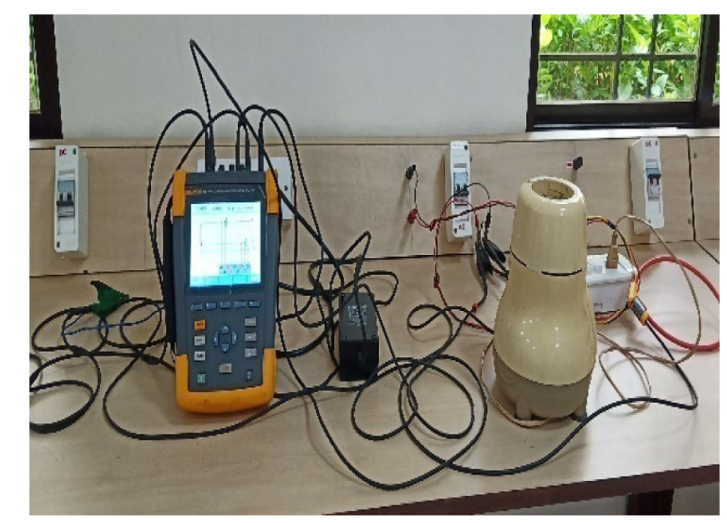

Fig. 9 Experimental test of the conventional mixer grinder

reduced amount of distortion than the existing in the application of a mixer grinder.
Table 7 Comparison of proposed simulated BLDC motor and experimental conventional mixer grinder under no-load condition

\begin{tabular}{lll}
\hline $\begin{array}{l}\text { No-load } \\
\text { condition }\end{array}$ & $\begin{array}{l}\text { Experimental } \\
\text { conventional mixer } \\
\text { grinder }(600 \mathrm{~W})\end{array}$ & $\begin{array}{l}\text { Proposed mixer } \\
\text { grinder simulated } \\
(200 \mathrm{~W})\end{array}$ \\
\hline $\begin{array}{c}\text { Amount of } \\
\text { distortion } \\
\text { (crest factor) }\end{array}$ & $\mathrm{Cf}=2.38$ & $\mathrm{Cf}=1.42$ \\
$\begin{array}{c}\text { Total harmonic } \\
\text { distortion }\end{array}$ & Voltage $=5 \%$ & Voltage $=3.35 \%$ \\
\hline
\end{tabular}

Table 8 Comparison of proposed simulated $48 \mathrm{~V}$ BLDC motor and experimental conventional mixer grinder at load condition

\begin{tabular}{lll}
\hline With load & $\begin{array}{l}\text { Experimental } \\
\text { conventional mixer } \\
\text { grinder }(600 \mathrm{~W})\end{array}$ & $\begin{array}{l}\text { Proposed mixer } \\
\text { grinder simulated } \\
(200 \mathrm{~W})\end{array}$ \\
\hline $\begin{array}{c}\text { Amount of } \\
\text { distortion (crest } \\
\text { factor) }\end{array}$ & $\mathrm{Cf}=2.06$ & $\mathrm{Cf}=1.38$ \\
$\begin{array}{c}\text { Total harmonic } \\
\text { distortion }\end{array}$ & Voltage $=4.8 \%$ & Voltage $=3.15 \%$ \\
\hline
\end{tabular}

\section{Conclusions}

In a MATLAB/Simulink, a proposed BLDC motor and existing universal motor for the application of a mixer grinder were simulated according to the specifications. The comparative efficiency and loss analysis were determined for the experimental convectional universal motor and BLDC motor. The starting torque in the BLDC motor can be observed to be higher than in the universal motor. Due to the absence of brushes friction, the $48 \mathrm{~V}$ BLDC motor had a higher efficiency than the universal motor working $230 \mathrm{~V}$ AC and $220 \mathrm{~V} \mathrm{DC}$. The losses in the $48 \mathrm{~V}$ BLDC motor were lesser than in the universal $230 \mathrm{~V}$ AC motor and the universal $220 \mathrm{~V}$ DC motor. In an existing system, the total harmonic distortion and crest factor are higher than the proposed system. 
Acknowledgements The authors would like to acknowledge Manipal Institute of Technology, MAHE, Manipal, India for their support of the research work.

Funding Open access funding provided by Manipal Academy of Higher Education, Manipal.

Conflict of interest The authors declare there is no conflict of interest.

Open Access This article is licensed under a Creative Commons Attribution 4.0 International License, which permits use, sharing, adaptation, distribution and reproduction in any medium or format, as long as you give appropriate credit to the original author(s) and the source, provide a link to the Creative Commons licence, and indicate if changes were made. The images or other third party material in this article are included in the article's Creative Commons licence, unless indicated otherwise in a credit line to the material. If material is not included in the article's Creative Commons licence and your intended use is not permitted by statutory regulation or exceeds the permitted use, you will need to obtain permission directly from the copyright holder. To view a copy of this licence, visit http://creativecommons.org/licenses/by/4.0/.

\section{References}

1. J.S. Kamalakannan, V. Narayanan, M. Karthi, Ramanathan, Design and development of DC powered BLDC motors for Mixer Grinder applications, in IEEE International Conference on Sustainable Green Building and Communities, Chennai (2016), pp. 1-6

2. S.N. Bhagat, D. Chinmay, B.G. Fernandes, Design and development of a sensorless controller for DC operated mixer grinders, in IEEE International Conference on Sustainable Green Building and Communities, Chennai (2016), pp. 1-6

3. F. Gholase, Design of efficient BLDC motors for DC operated mixer-grinders, in IEEE International Conference Industrial Technology, Seville, Spain (2015), pp. 696-701

4. P. Zaskalicky, J. Dupej, Modelling of universal motor supplied by harmonic voltages, in IEEE International Conference on Power Electronic and Control Motion (ICPECM), Portoroz, Slovenia (2006), pp. 1070-1073

5. N. Deekshitha, R. Shivarudra Swamy, Loss and efficiency analysis of universal motor used in mixer grinders by mathematical modelling, in IEEE International Conference on Automatic Control International Systems, Shah Alam, Malaysia (2018), pp. $105-110$

6. S.K. Poovizhi, L. Irene Priyadarshini, P. Ragul, Logambal, Investigation of mathematical modeling of BLDC motor drive by using Matlab-Simulink, in IEEE International Conference on Power and Embedded Drives Control, Chennai (2017), pp. $178-183$
7. A.B. Yildiz, Electrical equivalent circuit based modeling and analysis of direct current motor. Int. J. Electr. Power Energy Syst. 43(1), 1043-1047 (2012)

8. Y. Laxminarayana, Tarakalyani, modeling and simulation of BLDC motors for aiding and opposing load. IOSR J. Electr. Eng. 7(4), 9-17 (2013)

9. C. Mohankrishna, A. Ramesh, R.K. Gowd, S.R. Gupta, Modelling and simulation of BLDC motor using state space approaches. Int. J. Innov. Res. Electron. Electr. Inst. Control Eng. 4(5), 533-538 (2016)

10. D. Lin, S. Zhou, Analytical models and parameters computations for universal motor, in Proceeding IEEE IEMDC, Niagara Falls, Canada (2011), pp. 119-124

11. R. Wang, R.T. Walter, Modelling of universal motors performances and brush commutations using finite element computed inductances and resistances matric. IEEE Trans. Energy Convers. 15(3), 257-263 (2000)

12. G. Papa, B. Korousic Seljak, T. Kmecl, Universal motor efficiency improvement using evolutionary optimizations. IEEE Trans. Ind. Electron. 50(3), 602-611 (2003)

13. A. Gerlando, R. Perini, Equivalent circuits for the performances analysis of universal motor. IEEE Trans. Energy Convers. 19(1), 18-27 (2004)

14. J. Cros, P. Viarouge, Y. Chalifour, J. Figueroa, A New structures of universal motors using soft magnetic composite. IEEE Trans. Ind. Appl. 40(2), 550-557 (2004)

15. A. Gerlando, R. Perini, Model of the commutations phenomena in a universal motors. IEEE Trans. Energy Convers. 21(1), 27-33 (2006)

16. B.-K. Lee, M. Ehsani, Advanced simulation model for BLDC motor drive. Electr. Power Compon. Syst. 31(9), 841-868 (2003)

17. S. Latha, K. Satyendra, Design topology and electromagnetic field analysis of permanent magnets BLDC motors for electric scooter applications, in International Conference on Electrical, Electronics, and Optimization Techniques (2016), pp. 1541-1545

18. S Yosub, H. Niguchi, K. Noboru, Coupled analysis of BLDC motors using finite element methods \& back electromotive force detecting electrical circuit, in International Conference on Electrical Machines (2014), pp. 724-729

19. L. Chang, M. Jerzy, Design of the 5-phase permanent magnet BLDC motors for automobile, in IEEE Conference on Vehicular Technology (2003), pp. 3197-3201

20. M. Kondo, Parameters measurement for permanent magnet synchronous machines. IEEJ Trans. Electr. Electron. Eng. 2, 109-117 (2007)

21. P. Sekerak, Ferrites and different winding types in permanent magnet synchronous motors. J. Electr. Eng. 63(3), 162-170 (2012)

Publisher's Note Springer Nature remains neutral with regard to jurisdictional claims in published maps and institutional affiliations. 